ANADOLU, J. of AARI

ISSN: $1300-0225$ (Print)

E-ISSN: 2667-6087 (Online)

2021, 31 (2): 137-142

DOI: $10.18615 /$ anadolu. 1029812

\title{
The Effects of Modified Recurrent Selection on Fiber Characteristics and Neps in Cotton (Gossypium hirsutum L.)
}

\author{
Serife BALCI ${ }^{1} \quad$ Volkan Mehmet CINAR ${ }^{2} \mathbb{D}$ Aydin UNAY $Y^{3 *}$ \\ ${ }^{1}$ Cotton Research Institute, Nazilli, Aydın/TURKEY \\ ${ }^{2}$ Aydın Adnan Menderes University, Graduate School of Natural and Applied Sciences, Aydın/TURKEY \\ ${ }^{3}$ Aydın Adnan Menderes University, Faculty of Agriculture, Department of Field Crops, Aydin/TURKEY \\ ${ }^{1}$ https://orcid.org/0000-0001-8348-3674 $\quad{ }^{2}$ https://orcid.org/0000-0001-5822-5649 \\ ${ }^{3}$ https://orcid.org/0000-0002-7278-4428 \\ *Corresponding author (Sorumlu yazar): aunay@adu.edu.tr \\ Received (Geliş tarihi): 05.02.2021Ａccepted (Kabul tarihi): 28.04.2021
}

\begin{abstract}
The aim of this research was to evaluate the efficiency of the recurrent selection method for increasing ginning out-turn, optimizing fiber characters and neppiness in cotton breeding. This study started with the creation of $24 F_{I}$ combinations at Nazilli Cotton Research Institute in 2013. According to recurrent selection method, plants of 45 populations were evaluated for the first cycle of the recurrent selection procedure such that the $F_{1}: C_{1} S_{0}$ was evaluated in 2017 , the $F_{2}: C_{1} S_{I}$ in 2018 and the $F_{3}: C_{I} S_{2}$ in 2019. The fiber nep number and size decreased with each filial generation (from $F_{1}$ to $F_{3}$ ). Generally, high heritability coupled with genetic advance was estimated for ginning out-turn, fiber characters and neppiness. The results of inbreeding depression values indicated that ginning out-turn and fiber length in the population increased while the fibers became coarser under stable fiber strength. In addition, inbreeding depression for nep and SCN (Seed Coat Neps) number were higher than that of nep and SCN size. Our results showed that the recurrent selection method can be successfully applied in a cotton breeding program.
\end{abstract}

Keywords: Genetic advance, heritability, inbreeding depression, neppiness, recurrent selection.

\section{Pamukta (Gossypium hirsutum L.) Nep ve Lif Kalite Özellikleri Üzerine Modifiye Tekrarlamalı Seleksiyonun Etkisi}

ÖZ: Pamuk ıslahında yüksek çırçır randımanı, optimum lif kalite özellikleri ve düşük nep düzeyleri için tekrarlamalı seleksiyonun etkinliğini değerlendirmek amaçlanmıştır. Çalışma 2013 yılında Nazilli Pamuk Araştırma Enstitüsü̈nde 24 melez kombinasyonun oluşturulması ile başlamıştır. Tekrarlamalı seleksiyon yöntemi uyarınca 45 populasyona ait 2017 yılında $F_{I}$ $\left(C_{l} S_{0}\right), 2018$ yllında $F_{2} ; \quad\left(C_{1} S_{l}\right)$ ve 2019 yllında $F_{3}\left(C_{1} S_{2}\right)$ bitkileri tekrarlamall seleksiyonun ilk çemberi olarak değerlendirilmiştir. $F_{1}$ generasyonundan $F_{3}$ generasyonuna doğru elyaf neps sayısı ve büyüklüğünün azaldı̆̆ saptanmıştır. Çırçır randımanı, lif kalite özellikleri ve neps için genellikle yüksek düzeyde kalıtım derecesi ve genetik ilerleme tahminlenmiştir. Kendileme depresyonu sonuçları populasyonda sabit lif dayanıklılı̆̆ı koşullarında çırçır randımanının arttı̆̆ını buna karşın liflerin kabalaştı̆̆ını ortaya koymuştur. Elyaf nep ve tohum kabuğu nep (TKN) sayısı özellikleri için elyaf nep ve tohum kabuğu nep (TKN) büyüklüğ̈̈ özelliklerinden daha yüksek kendileme depresyonu görülmüştür. Çalışma sonuçlarımız pamuk ıslah programlarında tekrarlamalı seleksiyonun başarllı bir şekilde kullanılabileceğini göstermiştir.

Anahtar kelimeler: Genetik ilerleme, kalttım, kendileme depresyonu, nep, tekrarlamalı seleksiyon. 


\section{INTRODUCTION}

Cotton (Gossypium hirsutum L.) is one of the major crops of greatest economic importance in Turkey. Cotton varieties with higher yield and better quality have been bred in both our country and the world. The need for improvement of cotton fiber properties with longer, stronger and finer fibers is increasing due to competition with synthetics. Besides these three important fiber characteristics, neps (fiber tangles due to immature fibers) and seed coat fragments can slow productivity and do not absorb dye thus producing light flecks in the woven fabric during spinning and dyeing (Constable et al., 2015).

The variability for selection efficiency in a cotton breeding program depends on the existence of genetic variability for yield and fiber characters in the gene pool. In the breeding of self-pollinated crops, rapid homozygosity occurs in filial generations by pedigree or bulk selection. Thus, the number of genes that could be good combinations decreases at the same rate. In the meantime, selection success is adversely affected by decreasing variation due to successive selfgenerations (Toker and Cagirgan, 1995). Generation after generation of reselection is followed by intermating among selected plants to produce the population for the next cycle of selection. This process is defined as recurrent selection and included cycles of selection, evaluation and recombination (Gokidi et al., 2016). Among selection methods, recurrent selection increases genetic variability for further generations (Maich et al., 2000) and also increases the frequency of desirable genes controlling the target character and genetic recombination in terms of superior genotypes in the population (Abou $\mathrm{El}-$ Yazied et al., 2014). Recurrent selection in cotton was successfully applied by Miller and Rawlings (1967) for lint yield and Meredith and Bridge (1973) for lint percent and, significant improvements were reported in both studies compared to the base population. Yi et al. (2004) applied marker-assisted recurrent selection for cotton resistance to bollworm (Helicoverpa armigera) and found it to be a significant improvement compared to the preceding population. Abou El -Yazied et al. (2014) revealed that ginning out-turn of the second cycle of selection was higher than the base population $(13.3 \%$ and $17.73 \%)$ as a result of two recurrent selection cycles. Zeng and Meredith (2010) and Unay et al. (2019) reported genotypic differences for fiber neps and seed coat fragments in cotton. In addition, the correlation among yield and yield components and nep characters were evaluated by Zeng and Meredith (2009), Zeng and Bechere (2012) and Zeng et al. (2020). It has also been reported that the breeding of genotypes with mature and thinner fiber, high lint yield and neppiness is very difficult. Previous research showed the effects of recurrent selection on ginning out-turn and fiber characteristics. However, there are few studies about the effectiveness of selection for neps and seed coat fragments in a cotton hybrid population of different generations. Therefore, the present study was focused on determining the effectiveness of selection for fiber characteristics, neps and seed coat fragments using the recurrent selection procedure. In addition, genetic gain, heritability and inbreeding depression for the observed characters were estimated.

\section{MATERIAL and METHODS}

The $\mathrm{F}_{1}$ populations included 24 cross combinations that were developed from crossing four lines: Gloria, Claudia, Carmen, and Julia, and three testers: ST-468, Carisma and Flash (G. hirsutum L.) using reciprocal line $\mathrm{x}$ tester mating design in 2013. The genotypes used as parents were specially selected for lower seed coat neps (SCN) number and adaptive capacity. A total of 31 genotypes, 7 parents and their $24 \mathrm{~F}_{1}$ crosses were grown in randomized complete block design with three replications at the Cotton Research Institute, Nazilli, Aydın/Turkey in 2014 (Base population: $\mathrm{C}_{0} \mathrm{~S}_{0}$ ). The $\mathrm{F}_{2}$ seeds of all hybrid populations were sown in non-replicated rows $12.0 \mathrm{~m}$ long and 5.6 $\mathrm{m}$ wide. The 10 superior plants from all $\mathrm{F}_{2}$ plants were selected based on ginning out-turn (GOT), fiber fineness (FF), fiber length (FL), fiber strength (FS) and nep (number $\mathrm{g}^{-1}$ ) after HVI and AFIS laboratory analysis in $2015\left(\mathrm{C}_{0} \mathrm{~S}_{1}\right)$. The data for the top plants are given in Table 1 . 
Table 1. Average values for traits examined in the base population.

Çizelge 1. Temel populasyonda incelenen özelliklere ilişkin ortalama değerler.

\begin{tabular}{|c|c|c|c|c|c|}
\hline $\begin{array}{l}\text { Combination } \\
\text { Kombinasyon }\end{array}$ & $\begin{array}{c}\text { GOT } \\
\text { Çırçır randımanı } \\
(\%)\end{array}$ & $\begin{array}{c}\text { FF } \\
\text { Lif inceliği } \\
\text { (mic.) }\end{array}$ & $\begin{array}{c}\text { FL } \\
\text { Lif uzunluğu } \\
(\mathrm{mm})\end{array}$ & $\begin{array}{c}\text { FS } \\
\text { Lif dayanıkl11lı̆ } \\
\left(\mathrm{g} \mathrm{tex}^{-1}\right)\end{array}$ & $\begin{array}{c}\text { Nep } \\
\text { Elyaf nep sayis1 } \\
\left(\text { number } \mathrm{g}^{-1}\right)\end{array}$ \\
\hline Gloria x Carisma & 42.57 & 4.64 & 30.11 & 33.80 & 22 \\
\hline Gloria x Carisma & 40.95 & 4.96 & 30.46 & 30.13 & 48 \\
\hline Gloria x Flash & 43.04 & 4.95 & 31.95 & 39.96 & 40 \\
\hline Gloria x Flash & 44.66 & 4.67 & 30.87 & 35.66 & 38 \\
\hline Carisma x Carmen & 48.89 & 4.72 & 31.72 & 33.19 & 44 \\
\hline Julia x ST 478 & 42.86 & 4.60 & 33.65 & 30.43 & 28 \\
\hline Carmen x Carisma & 40.16 & 4.89 & 31.54 & 36.39 & 24 \\
\hline Carmen x ST 468 & 45.50 & 4.59 & 29.52 & 31.22 & 38 \\
\hline Julia x ST 468 & 44.03 & 3.76 & 29.72 & 31.29 & 56 \\
\hline ST 468 x Claudia & 44.36 & 4.83 & 30.82 & 31.23 & 54 \\
\hline
\end{tabular}

GOT: Ginning out-turn, FF: Fiber fineness, FL: Fiber length, FS: Fiber strength.

In the 2016 season, the best $F_{3}$ plants were crossed according to a half diallele mating procedure to produce 45 hybrids as possible combinations. The 45 hybrid combinations were sown in nonreplicated rows for selfing to produce $\mathrm{F}_{2}$ seeds in $2017\left(\mathrm{C}_{1} \mathrm{~S}_{0}\right)$. The $\mathrm{F}_{2}(\mathrm{C} 1 \mathrm{~S} 1)$ and $\mathrm{F}_{3}\left(\mathrm{C}_{1} \mathrm{~S}_{2}\right)$ plants of the 45 populations were sown as mentioned in the first cycle with selection applied at $10 \%$ intensity to obtain the best $F_{3}$ families in 2018 and 2019. All plants were separately harvested by hand and ginned on laboratory-type roller gins with no lint cleaning. The fibers of plant samples were analyzed by HVI (High Volume Instruments). Firstly, the plants were selected from each combination and generation for higher GOT $(\geq 40 \%)$, FL ( $\geq 30 \mathrm{~mm})$, FS $\left(\geq 32 \mathrm{~g} \mathrm{tex}^{-1}\right)$ and optimum FF (3.9-4.9 mic.). The nep size $(\mu \mathrm{m})$, nep (number $\mathrm{g}^{-1}$ ), seed coat nep size (SCN; $\mu \mathrm{m}$ ) and seed coat nep ( $\mathrm{SCN}$; number $\mathrm{g}^{-1}$ ) of superior plants were measured using USTER AFIS by ISKUR Textile Company. The best 10 plants were determined by selection in terms of low nep properties.

In this research, we evaluated the $F_{1}, F_{2}$ and $F_{3}$ populations in cycle 1 of recurrent selection for ginning out-turn, fiber characteristics and nep criteria. Each plot was in two $12 \mathrm{~m}$ long rows, the row and plant spacing were $0.7 \mathrm{~m}$ and $0.2 \mathrm{~m}$. All plantings were carried out in May and cultural practices were managed as recommended for the cotton growing of the Aegean Region. The narrowsense heritability $\left(h^{2}\right)$ was calculated for $F_{2} / F_{1}$ and $\mathrm{F}_{3} / \mathrm{F}_{2}$ progenies as described by Smith and Kinman (1965): $\mathbf{h}^{2}=\mathbf{b}_{\text {op }} / \mathbf{r}_{\text {op }}$ where,

$\mathrm{h}^{2}=$ narrow sense heritability

$b_{\mathrm{op}}=$ regression coefficient or slope of parentoffspring

$r_{o p}=$ correlation of parent-offspring

Regression and correlation coefficients used to estimate heritability were calculated using $\mathrm{JMP}^{\circledR}$ 13 statistical software program (SAS Institute Inc. 2016). Heritability estimates were grouped as high $(>50 \%)$, moderate, $(20$ to $50 \%)$, and low $(<20 \%)$ as suggested by Stansfield (1986).

Genetic advance as a percentage of mean was calculated according to Falconer and Mackay (1996) by the following formula;

$\mathbf{G A}=$ mean of trait $/\left[\mathbf{i} \times \mathrm{h}^{\mathbf{2}} \times\left(\boldsymbol{\sigma}^{2} p\right)^{1 / 2}\right] * \mathbf{1 0 0}$ where, $\mathrm{i}=$ selection intensity for trait

$\mathrm{h}^{2}=$ heritability for trait

$\sigma_{p}^{2}=$ phenotypic variance of trait

Selection intensity at 5\% will be 2.063 was assumed in predicting direct selection response.

\section{RESULT and DISCUSSION}

The ginning out-turn efficiency, which was $41.53 \%$ in the $\mathrm{F}_{1}$ generation, was $41.08 \%$ in the $\mathrm{F}_{2}$ generation, whereas it was $43.51 \%$ in the $F_{3}$ generation (Table 2). Similarly, there was an increase in fiber length. The increase from $\mathrm{F}_{1}$ to $\mathrm{F}_{3}$ was $4.76 \%$ for GOT and $2.44 \%$ for $\mathrm{FL}$. Unfortunately, FF in our population became 
coarser, increasing by $7.32 \%\left(\mathrm{~F}_{1}-\mathrm{F}_{2}\right)$ and $11.67 \%$ $\left(\mathrm{F}_{1}-\mathrm{F}_{3}\right)$. As a result of the selection applied, FS remained stable throughout generations.

The nep number decreased with each filial generation (from $F_{1}$ to $F_{3}$ ) (Table 2). Similarly, nep size decreased in $F_{2}$ compared to $F_{1}$ and remained constant at $\mathrm{F}_{3}$. According to USTER statistics (Anonymous, 2021), nep number ranging from 53.78 to 84.76 (number $\mathrm{g}^{-1}$ ) falls in the low class. The SCN number decreased from $F_{1}$ (17.56) to $F_{3}$ (7.51) generation, whereas SCN size increased by $6.51 \%$. According to USTER classification, the number of $\mathrm{SCN}$ in the $\mathrm{F}_{2}$ and $\mathrm{F}_{3}$ generations was in the low group indicating that the population evolved positively in terms of characters. The nep and SCN number found in all three generations were lower than the values found by Zeng et al. (2020) in $F_{4}$ progeny rows in response to selection of top $20 \%$ of the $\mathrm{F}_{3}$ for reduced neppiness, whereas the nep and SCN size values were similar.

The heritabilities calculated based on the $\mathrm{F}_{1}: \mathrm{F}_{2}$ generations were high except for FL and SCN number (Table 3). All heritabilities calculated over the $F_{2}: F_{3}$ generations were high (Table 3 ) or very high according to Stansfield (1986). The higher heritability found for the $F_{2}: F_{3}$ indicated that the additive gene effect increased in advanced generations. Abou El-Yazied et al. (2014) stated that high heritability for GOT and fiber characters were estimated through both the first recurrent cycle $\left(\mathrm{C}_{1}\right)$ and second cycle $\left(\mathrm{C}_{2}\right)$ in cotton. Zeng et al. (2020) reported that the heritabilities for nep and SCN number were higher than that of nep and SCN size and that fewer nep number was useful for selections of neppiness across population of cotton. High levels of heritability indicate that recurrent selection was useful to accumulate desirable genes for these traits. The high heritability for observed characters also indicated that important genetic variability persisted in our material. In addition, this variability was sufficient for providing a substantial amount of improvement through the selection of superior progenies in the recurrent selection method.

Table 2. Mean performance in $\mathrm{F}_{1}, \mathrm{~F}_{2}$ and $\mathrm{F}_{3}$ generations through first recurrent selection cycle $\left(\mathrm{C}_{1}\right)$.

Çizelge 2. Tekrarlamalı seleksiyonun ilk döngüsünde $\left(\mathrm{C}_{1}\right) \mathrm{F}_{1}, \mathrm{~F}_{2}$ ve $\mathrm{F}_{3}$ generasyonlarına ilişkin ortalama değerler.

\begin{tabular}{|c|c|c|c|}
\hline \multirow{2}{*}{$\begin{array}{l}\text { Character } \\
\text { Özellik }\end{array}$} & \multicolumn{3}{|c|}{$\begin{array}{c}\text { Generations } \\
\text { Generasyonlar }\end{array}$} \\
\hline & $\mathrm{F}_{1}$ & $\mathrm{~F}_{2}$ & $\mathrm{~F}_{3}$ \\
\hline Ginning out-turn / Çırçır randımanı & $41.53 \pm 0.31$ & $41.08 \pm 0.26$ & $43.51 \pm 0.22$ \\
\hline Fiber length / Lif uzunluğu & $30.72 \pm 0.19$ & $30.24 \pm 0.10$ & $31.47 \pm 0.11$ \\
\hline Fiber fineness / Lif inceliği & $4.37 \pm 0.06$ & $4.69 \pm 0.04$ & $4.88 \pm 0.03$ \\
\hline Fiber strength / Lif dayanıklılı̆ğ & $3.80 \pm 0.47$ & $32.25 \pm 0.22$ & $33.27 \pm 0.21$ \\
\hline Nep (number $g^{-1}$ ) / Elyaf nep sayıs1 & $84.76 \pm 4.81$ & $65.18 \pm 2.56$ & $53.78 \pm 2.07$ \\
\hline Nep size $(\mu \mathrm{m}) /$ Elyaf nep büyüklüğü & $765.98 \pm 8.33$ & $724.93 \pm 6.53$ & $727.93 \pm 5.68$ \\
\hline SCN (number $\mathrm{g}^{-1}$ ) / Tohum kabuğu nep sayısı & $17.56 \pm 1.55$ & $7.22 \pm 0.50$ & $7.51 \pm 0.41$ \\
\hline SCN size $(\mu \mathrm{m})$ / Tohum kabuğu nep büyüklüğü & $1,183.16 \pm 18.50$ & $1,289.38 \pm 29.59$ & $1,260.09 \pm 22.46$ \\
\hline
\end{tabular}

Table 3. Genetic advance, heritability and inbreeding depression values in different generations.

Çizelge 3. Farklı generasyonlara ilişkin genetik ilerleme, kalıtım derecesi ve kendileme depresyonu değerleri.

\begin{tabular}{|c|c|c|c|c|c|c|c|}
\hline \multirow[t]{2}{*}{$\begin{array}{l}\text { Character } \\
\text { Özellik }\end{array}$} & \multicolumn{2}{|c|}{$\begin{array}{l}\mathrm{h}^{2} \text { (narrow sense) } \\
\text { (Dar anlamda } \\
\text { kalitım derecesi) }\end{array}$} & \multicolumn{2}{|c|}{$\begin{array}{l}\text { Genetic advance } \\
\text { Genetik ilerleme } \\
\text { (\%) }\end{array}$} & \multicolumn{3}{|c|}{$\begin{array}{l}\text { Inbreeding depression } \\
\text { Kendileme depresyonu } \\
(\%)\end{array}$} \\
\hline & $\mathrm{F}_{1}: \mathrm{F}_{2}$ & $\mathrm{~F}_{2}: \mathrm{F}_{3}$ & $\mathrm{~F}_{2}$ & $\mathrm{~F}_{3}$ & $\mathrm{~F}_{1}: \mathrm{F}_{2}$ & $\mathrm{~F}_{2}: \mathrm{F}_{3}$ & $\mathrm{~F}_{1}: \mathrm{F}_{3}$ \\
\hline GOT / Çırçır randımanı & 0.87 & 0.84 & 7.55 & 5.81 & 1.10 & -5.91 & -4.75 \\
\hline FL / Lif uzunluğu & 0.44 & 0.96 & 2.28 & 4.67 & 1.57 & -4.08 & -2.45 \\
\hline FF / Lif inceliği & 0.59 & 0.74 & 6.40 & 5.53 & -7.32 & -3.97 & -11.59 \\
\hline FS / Lif dayanıklılığı & 0.47 & 0.94 & 4.34 & 8.03 & 4.60 & -3.16 & 1.58 \\
\hline Nep $\left(\right.$ number $\mathrm{g}^{-1}$ )/ Nep sayıs1 & 0.53 & 0.80 & 28.41 & 42.43 & 23.10 & 17.49 & 36.55 \\
\hline Nep size $(\mu \mathrm{m}) /$ Nep büyüklüğü & 0.82 & 0.87 & 10.11 & 9.26 & 5.36 & -0.41 & 4.97 \\
\hline SCN (number $\mathrm{g}^{-1}$ ) / Tohum kabuğu nep sayısı & 0.30 & 0.81 & 28.67 & 59.92 & 58.86 & -4.00 & 57.22 \\
\hline SCN size $(\mu \mathrm{m}) /$ Tohum kabuğu nep büyüklüğü & 0.98 & 0.76 & 30.63 & 18.42 & -8.98 & 2.27 & -6.50 \\
\hline
\end{tabular}


It was reported that measuring heritability alone does not give a complete idea about the expected gain in the next generation but that it must be considered in conjunction with genetic advance (Dhivya et al., 2014). When the genetic advance as a percentage of mean values in terms of GOT and fiber characters was evaluated, higher values were recorded for GOT and FS (Table 3). Similarly, Kumar et al. (2019) found that high heritability was associated with a high genetic advance in terms of ginning out-turn. It was remarkable that genetic progression was very limited especially for FF and FL. Despite this, the results indicate that selection could be successful especially in terms of ginning out-turn which had high heritability and genetic advance.

The highest genetic advance was recorded for SCN number, whereas nep size had the lowest genetic advance values (10.11 and 9.26). The high level of genetic advance values for SCN size, SCN number and nep number were due to the high phenotypic variances of these characters. Thus, all characters of nep fragment having moderately high heritability and genetic advance could be improved by an effective selection in cotton breeding programs aimed at reducing nep fragments.

\section{REFERENCES}

Abou El-Yazied, M. A., Y. A. M. Soliman, and Y. M. ElMansy. 2014. Effectiveness of recurrent selection for improvement of some economic character in Egyptian cotton. Egypt Journal Agricultural Research 92(1): 135-151.

Anonymous, 2021. USTER AFIS PRO 2 Application Report. A new single fiber testing system for the process control in spinning mills. Available at: https://www.uster.com.

Constable, G. A., D. J. Llewellyn, S. A. Walford, and J. D. Clement. 2015. Cotton breeding for fiber quality improvement. Chapter:10. In: D. M. Cruz and D. Dierig $(E d s)$. Industrial Crops: Breeding for Bioenergy \& Bio-products. Springer Science Business Media.

Dhivya, R., P. Amalabalu, R. Pushpa, and D. Kavitha. 2014. Variability, heritability and genetic advance in upland cotton (Gossypium hirsutum L.). African Journal of Plant Science 8(1): 1-5.
Inbreeding depression was found to be moderately negative for GOT and FL; highly negative for FF in $F_{2}: F_{3}$ and $F_{1}: F_{3}$, while $F S$ exhibited an unstable situation in terms of inbreeding depression (Table 3 ). These results indicated that the ginning out-turn and fiber length in the population increased while the fibers became coarser under stable fiber strength. Inbreeding depression for nep and SCN number was higher than that of nep and SCN size.

\section{CONCLUSION}

The performance of $\mathrm{F}_{3}$ generations for fiber length, fiber strength and neppiness was at a desirable level for selecting promising genotypes. Selection for high ginning out-turn and neppiness may increase fiber fineness. Neppiness was first evaluated as a selection criterion for recurrent selection in cotton breeding.

\section{ACKNOWLEDGEMENTS}

Volkan Mehmet CINAR thanks the Higher Education Council of Turkey (YOK) for 100/2000 PhD scholarship.

Falconer. D.S., and T.F. Mackay. 1996. Introduction to quantitative genetics. 4th Ed Benjamin Cummings UK.

Gokidi, Y., A. N. Bhanu, and M. N. Singh. 2016. Marker assisted recurrent selection: an overview. Advances in Life Sciences 5(17): 6493-6499.

Kumar, C. P. S., S. Raju, E. B. Rajan, A. Muraleedharan, and D.B. Suji. 2019. Studies on genetic variability, heritability and genetic advance in cotton (Gossypium hirsutum L.). Plant archives 19(1): 934-937.

Maich, R. H., Z. A. Gaido, G. A. Manera, and M.E. Dubois. 2000. Two cycles of recurrent selection for grain yield in bread wheat. Direct effect and correlated responses. Agriscientia 17: 35-39.

Meredith, W. R., and R. R. Bridge. 1973. Recurrent selection for lint percent within a cultivar of cotton (Gossypium hirsutum L.). Crop Science 13(6): 698-701.

Miller, P. A., and J. D. Rawlings. 1967. Selection for increased lint yield and correlated responses in Upland cotton, Gossypium hirsutum L. Crop Science 7: 637640 . 
SAS Institute Inc. 2016. JMP Statistical Software, Version 13 Cary, USA.

Smith, J. D., and M. L. Kinman. 1965. The use of parentoffspring regression as estimation of heritability. Crop Science 5 6): 595-596.

Stansfield, W. D. 1986. Theory and Problems of Genetics. McGraw- Hill New York.

Toker, C., and I. Cagirgan. 1995. Application of the recurrent selection method in self-pollinated plants. Akd. Ü. Ziraat Fakültesi Dergisi 8: 264-270.

Unay, A., S. Balci, and V. M. Cinar. 2019. Gene action and combining ability for neps and seed coat neps in cotton (Gossypium hirsutum L.). Turkish Journal of Field Crops 24 2): 211-214.

Yi, C., W. Guo, and X. Zhu. 2004. Pyramiding breeding by marker assisted recurrent selection in upland cotton II. selection effects on resistance to Helicoverpa armigera. Science Agriculture Sin, 37: 801-807.

Zeng, L., and W. R. Jr. Meredith. 2009. Associations among lint yield, yield components, and fiber properties in an introgressed population of cotton. Crop Science 49: $1647-1654$

Zeng, L., and W. R. Jr. Meredith. 2010. Neppiness in an introgressed population of cotton: genotypic variation and genotypic correlation. Journal of Cotton Science 14: $17-25$.

Zeng, L., and E. Bechere. 2012. Combining ability for neps, seed coat fragments, and motes in Upland cotton. Journal of Cotton Science 16: 17-26.

Zeng, L., E. Bechere, and C. D. Delhom. 2020. Potential for genetic improvement of neppiness traits in upland cotton. Crop Science 60: 1876-1883. 